\title{
HENRI BERGSON: SCIENCE, LIFE-SCIENCE, PHILOSOPHY AND THE HUMAN CONDITION
}

\author{
PhD. Raz SHPEIZER, \\ Kaye Academic College of Education, \\ ISRAEL, \\ Email: razsp@yahoo.com
}

\begin{abstract}
The developments in 19th century life-science were, in many ways, a continuation of the scientific revolution that begun in the 16th century. Yet, these developments also marked a new era, since now not only matter, but also life and humans, could, ostensibly, be understood within the scientific paradigm. In the article, I argue that these developments met with two basic and polarized responses, which are manifested in the dichotomy between modernism and postmodernism. Moreover, this dichotomy continues to divide both the academic world and society more generally. However, I suggest that there is a third possible response, one taken by Henri Bergson and one that has received much less attention. This response offers a middle way between these extremes, acknowledging scientific achievements yet emphasizing the uniqueness of life and human existence. It thus seeks to maintain the autonomy of the study of life and of philosophy as a life-oriented discipline.
\end{abstract}

Keywords: Henri Bergson; Science; Life-Science; Philosophy; Human Condition;

\section{INTRODUCTION}

On October $18^{\text {th }}, 2019$, occurred the $160^{\text {th }}$ anniversary of the birthday of the French philosopher Henri Louis Bergson, one of the most influential philosophers at the beginning of the $20^{\text {th }}$ century. I think that it is quite safe to say that this birthday has not been celebrated in too many places around the world, despite voices that are being heard from time to time claiming a renaissance of Bergsonism. I do believe, however, that there are good reasons why Bergsonism, or rather Henri Bergson's Philosophy, should be revived, some of which I would like to outline in this paper.

Curiously enough, and one may say ironical too, Bergson's year of birth was the same year in which Charles Robert Darwin's On the Origin of Species by way of Natural Selection was first published. ${ }^{1}$ The irony here is two-faced. First, Bergson, despite the great appreciation he had for science, especially for (then) modern biology, tried to exceed and in a way overcome it, so much so that one could say that his entire philosophy engages in this mission. In each of his major books, as in most of his articles and lectures, Bergson takes on a central scientific theme, and while accepting and using many of the scientific discoveries and theories, he nevertheless criticizes, corrects and attempts to go beyond them. His bestknown book, The Creative Evolution (L'Evolution Creatrice), ${ }^{2}$ is devoted to debating Darwinism and $19^{\text {th }}$ century life-science. The second and bitter side of the irony is that while

\footnotetext{
${ }^{1}$ Charles R. Darwin, On the Origin of Species by Means of Natural Selection, or the Preservation of Favoured Races in the Struggle for Life, Penguin, London, 1859/1985.

${ }^{2}$ Henri L. Bergson, The Creative Evolution, Dover, New York, 1907/1983 (Translated by A. Mitchell).
} 
most of the world continues to celebrate Darwin's most notable work and his overall achievements, those of Bergson's seems to be rather neglected and forgotten.

What was it in modern science in general and particularly modern biology that evoked Bergson's reaction and motivated his entire philosophical project? And what can we learn, or rather should learn, from this project?

\section{THE DOUBLE SCIENTIFIC REVOLUTION}

The developments in $19^{\text {th }}$ century life-science, led by Darwin's theory of evolution and later by Mendel's Genetics, were a continuation of what is traditionally referred to as the scientific revolution, that took place in Europe since the Renaissance. ${ }^{3}$ The main characteristics of this revolution have been vastly addressed in the literature, and therefore need only be described briefly.

(1) A growing reliance on empirical data, combined with the elaboration of the experimental method, ${ }^{4}$ which was supported and enhanced by technological developments.

This empirical approach was combined with:

(2) Mathematization and geometrization of the empirical data, ${ }^{5}$ under the assumption that all natural phenomena can be understood and described in mathematical and geometrical formulas. In Galileo's famous words: "Philosophy is written in this grand book, the universe... but the book is written in the language of mathematics, and its characters are... geometric figures." 6

(3) Materialization and mechanization of the world view, ${ }^{7}$ that usually were combined with determinism, such as to form a picture of the universe as a product of the necessary motions of matter, that themselves are the necessary outcome of natural laws.

(4) Naturalization and objectivization of all methods and foundations of knowledge, ${ }^{8}$ so there is no place nor need for "that hypothesis," in Pierre Laplace's words, of God $;{ }^{9}$ and even more, though not as clearly pronounced, no room for what is subjective in essence, namely, consciousness and its related phenomena. ${ }^{10}$

To be sure, all these characteristics are intimately linked - a point that will soon be made explicit. But what is important to notice is that $19^{\text {th }}$ century life-science applied them both as techniques and as presupposition, and in so doing marked a new era. ${ }^{11}$ For it was no longer only the realm of matter that could be explained within this framework, but also the realm of life, that from now on will be understood as just another phenomena in the materialmechanical-natural world.

What were the consequences of this double revolution? At least from one perspective, it formed, as Sigmund Freud put it, a huge assault on humanity's views of itself. ${ }^{12}$ It deprived humanity of its assumed position in the center of the universe (the Copernican boost to the first scientific revolution); from its conviction of being at the center of earth and the crown of creation (the evolution theory); and in short, from its belief in its uniqueness and its special place in the world. It went, however, even deeper. For the process of digesting the new scientific paradigm seemed to yield a necessary and rational rejection of a whole cluster of

\footnotetext{
${ }^{3}$ While there is an ongoing debate as to whether the concept of revolution is suitable for describing the changes that occurred in the scientific realm during the early modern period, there is a wide agreement that this realm has undergone fundamental transformation, which profoundly affected society and culture. Here, in order to emphasize this transformation and its consequences, I will continue to use the phrase scientific revolution, without committing to a view of sharp and clear-cut historical boundaries. On this subject see: John P. McKay, A History of Western Society: From the Renaissance to 1815, Vol. B ( ${ }^{\text {th }}$ ed.), Bedford/St. Martin's, Boston, 2005; Thomas Nickles, Scientific Revolutions (winter 2017), in E. Zalta (ed.), Stanford Encyclopedia of Philosophy. Retrieved from https://plato.stanford.edu/archives/win2017/entries/scientific-revolutions (accessed 29.01.2020).
} 
beliefs that went together under the old worldview. Not only the belief in God was undermined - and in fact it was possible to leave this belief intact by putting God as a nonintervening creator, as did many (e.g., Deism) - but the beliefs in human freedom, creativity, autonomy and even, as aforesaid, the belief in subjectivity itself. For under the new scientific paradigm, all subjective phenomena were claimed to be nothing but an illusion, epiphenomena, no more. ${ }^{13}$

\section{THE DUAL REACTION TO THE SCIENTIFIC REVOLUTION}

Of course, these consequences of the scientific revolution did not occur at once but were taking shape in a long process. It is my claim that this process is still going on and its fruits, not all tasty and healthy, are actively present in our days, on all levels of life theoretical as well as practical. It is also my contention that there were, and still are - though in a changing outfit - two basic and polarized responses to the double scientific revolution, especially the second, life-science one. These responses are manifested in the dichotomy between modernism and postmodernism.

Now, while it is clear that these titles were not chosen arbitrarily, it is important that they will not be understood, in the present context, as encompassing too much or too little. Especially, they should not be understood solely in their historical connotation, that is, as only describing different historical phases, because I claim them to exist concurrently. Therefore, there is a need to explain what is meant by the claim that they are the basic reactions to the first, and mainly the second, phase of the scientific revolution.

By modernism I mean the philosophical and cultural reaction which accepts science as the only guide to truth and rejects as false all other methods and ways. Here we find the philosophical expression of an attitude which Richard Double calls "Philosophy as continuous with science,"14 i.e., philosophy which adopts and follows the main epistemological, metaphysical and methodological presuppositions of science. On the broad cultural level, we find a total secular approach, as well as different kinds of scientism, which

${ }^{4}$ Floris H. Cohen, The Scientific Revolution: A Historiographical Inquiry, University of Chicago Press, Chicago, 1994; David Wootton, The Invention of Science: A New History of the Scientific Revolution, Penguin, London, 2015.

${ }^{5}$ Piers Bursill-Hall, (2002, May 1). Why do We Study Geometry? Answers Through the Ages. The Department of Pure Mathematics and Mathematical Statistics, University of Cambridge, (C2001. Retrieved from https://www.dpmms.cam.ac.uk/ piers/F-I-G_opening_ppr.pdf (accessed 20.01.2020); D. Wootton, The Invention of Science: A New History of the Scientific Revolution.

${ }^{6}$ Peter K. Machamer (ed.), The Cambridge Companion to Galileo, Cambridge University Press, Cambridge, 1998, p. 64.

${ }^{7}$ Richard S. Westfall, The Construction of Modern Science: Mechanisms and Mechanics, Cambridge University Press, Cambridge, 2009.

${ }^{8}$ J. P. McKay, A History of Western Society: From the Renaissance to 1815.

${ }^{9}$ Carl B. Boyer, A History of Mathematics, Wiley, New York, 1968, p. 538.

${ }^{10}$ Edwin A. Burtt, The Metaphysical Foundations of Modern Science, Routledge \& Kegan Paul, London, 2001; Steven Shapin, The Scientific Revolution, The University of Chicago Press, Chicago, 1996.

${ }^{11}$ Though it was Mendel, rather than Darwin, who laid the mathematical foundations of evolutionary biology. See, for example, Vitezslav Orel, Mendel, Oxford University Press, Oxford, 1984 (Translated by S. Finn).

${ }^{12}$ Sigmund Freud, A General Introduction to Psycho-Analysis, Boni \& Liveright, New York, 1922 (Translated by G. Stanley), p. 247. Freud added psychoanalysis to this continuum, as to form the "three big blows" to humanity, but here I leave aside the third one.

${ }^{13}$ E. A. Burtt, The Metaphysical Foundations of Modern Science; Alan B. Wallace, The Taboo of Subjectivity: Toward a New Science of Consciousness, Oxford University Press, Oxford, 2004.

${ }^{14}$ Richard Double, Metaphilosophy and Free Will, Oxford University Press, New York, 1992, pp. 22-32. 
reject, as stated, all other views about life as nonsense. By postmodernism I mean, on the contrary, the philosophical attitude which rejects any interpretation of science as a privileged way of knowledge and claims it - as do Richard Rorty ${ }^{15}$ and Jean-François Lyotard ${ }^{16}$ for example - to be just another way of storytelling. On the broad cultural level, this attitude reveals itself in varied ways. For instant, skepticism, or the relativization of both truth and values, but also - and this is an expansion of the usual meaning of the term - in various kinds of fundamentalism. One should think here about occurrences like the Scopes Monkey Trial, the creationism versus evolutionism debate, or, from another perspective, on Umberto Eco's novel Foucault's Pendulum, ${ }^{17}$ where a straight and un-mistakable line is drawn between the "anything goes" attitude and religious-fundamental one.

Of course, one can argue against the above use of the terms modernism and postmodernism, claiming it is inaccurate. However, it should be noted that these terms are not being used here as rigid definitions but rather as a suggestive tool which attempts to pick out and identify some of the main reactions and processes that followed the double scientific revolution. What is more important is that three main features, which can be identified as emerging from the analysis above of the reactive processes to the scientific revolution, should be quite acceptable. These features are, firstly, that in both reactions, philosophy is no longer taken to be a leading, or even autonomous, discipline that seeks the truth in its own right and in its own way. That is to say that, for the modernists, philosophy is coming to be primarily a critical tool, which mainly support and clarify the scientific (as well as other) discourses; ${ }^{18}$ while for the postmodernists, philosophy, as much as science, is now just another way of talking and writing. ${ }^{19}$ Secondly, that these opposite reactions, although not the only reactions to the double scientific revolution, do represent the most basic and wide-spreading reactions to it, both by the academics and the general public, and thus represent an ever-growing mutual antagonism and dichotomy both in society in general and in the sphere of knowledgeseeking. Thirdly, that underneath the first two points and of the overall reaction to the double scientific revolution, there lies true confusion and an attempt to deal with an all new picture of the world; a picture in which, as stated above, not only is there no need for God, but also the very sense of subjectivity is being challenged, as are the beliefs in autonomy, freedom, and telos of life and in life.

It is exactly here, at the diachronic clashing point between past and present worldviews and the synchronic clashing point of reactions that follows it, that Bergson can be of great assistance. His relevance and significance are due to the fact that - unlike the two basic reactions to the scientific revolution - his reaction to the diachronic clash does not take the shape of either a regressive, aggressive, or submissive attitude which are so often the identifying mark of human reaction to big changes. Thus, Bergson is able to offer a third, middle way and balanced approach to the revolution that has shaken humanity so deeply.

\footnotetext{
${ }^{15}$ Richard Rorty, Objectivity, Relativism, and Truth: Philosophical Papers, Vol. 1, Cambridge University Press, Cambridge, 1991.

${ }^{16}$ Jean-François Lyotard, The Postmodern Condition: A Report on Knowledge, Minnesota University Press, Minneapolis, 1984 (Translated by G. Bennington \& B. Massumi).

${ }^{17}$ Umberto Eco, Foucault's Pendulum, Ballantine Books, New York, 1989 (Translated by W. Weaver).

${ }_{18}$ Stephen R. C Hicks, Explaining Postmodernism: Skepticism and Socialism from Rousseau to Foucault, Scholargy Publishing, Tempe, AZ, 2004.

${ }^{19}$ See, e.g., Richard Rorty, "Philosophy as a kind of writing: An essay on Derrida," in New Literary History 10/1 (1978), pp. 141-160.
} 


\section{REVOLUTION \\ 3. BERGSON'S ALTERNATIVE REACTION TO THE SCIENTIFIC}

\subsection{The Middle Way}

As mentioned, in all his major works Bergson referred directly to science, showed respect for science and invested lot of time studying its findings and methods. He understood, appreciated and accepted the gains made by science. Bergson was not, then, a postmodernist. However, he was not a blind follower either. He critically examined science, and his findings led him both to draw the limits of science and the scientific way and to offer a different method of knowledge that would not substitute science, but will work shoulder to shoulder with it, exploring levels of reality which science, as his investigation showed, could not reach. In this way, Bergson aimed both at recovering the traditional place of philosophy as a central discipline of knowledge and defending humanity`s fundamental beliefs that were shaken so hard by the scientific revolution. Bergson then, was not either what has been defined above as modernist.

Bergson's most famous book, The Creative Evolution, deals directly with life-science and life as such. In it, Bergson examines in depth the scientific developments in the field of Biology. Still more, he accepts what he takes to be the factual content of this science, that is, he accepts evolution as a proven fact and even makes it the cornerstone of his philosophical outlook. ${ }^{20}$ However, Bergson rejects the interpretation that the new science gives to the facts; rejects it, as will be shown, for three reasons: as not being sufficiently coherent; and - in a deeper level, as being the outcome of epistemological misunderstanding that farther leads to a metaphysical misconception.

\subsection{The Argument from Coherence and the Élan Vital}

Before turning to this last issue, there is a need to point out that knowledgeable as he was, Bergson - as most of his generation - could not appreciate the full scale of the genetic discoveries of George Mendel which are, alongside Darwin's theory of evolution, the cornerstone of modern biology, simply because that in his time Mendel's ideas were hardly known and understood. Hence Bergson referred much more to Darwin's theory and to the science of embryology which was developing rapidly at the time. Having said this, however, it is quite remarkable to notice that it is possible to read Bergson's arguments in the first part of the The Creative Evolution as arguments against the present day evolutionary biology, that is, biology that attempts to explain evolution in a mechanical and statistical way by combining Darwin's concept of evolution by natural selection with Mendelian genetics. ${ }^{21}$

Regarding the incoherence of the Darwinian theory of evolution, the central argument in The Creative Evolution is that no mechanistic model of evolution can sufficiently explain neither the parallel lines of evolution, nor its growing (in some directions) complexity. Without entering too deep into these argument, since, as will immediately become clear, this subject will lead us too far from the main purpose of this paper - we can note that, as to the first claim, Bergson argues that it is not reasonable to suppose that accidently almost the same organs (eyes, ears, etc.) were developed in different and remote species, classes or even subphylum such as vertebrate and invertebrate, even though those were separated before the organs developed.

\footnotetext{
${ }^{20}$ Magda C. Carvalho \& Maria P. Neves, "Building the 'true evolutionism': Darwin's impact on Henri Bergson's thought," in Revista Portuguesa de Filosofia 66/3 (2010), pp. 635-642.

${ }^{21}$ María D. I. Wolsky, \& Alexander A. Wolsky, "Bergson's vitalism in the light of modern biology," in Frederick Burwick \& Paul Douglass (eds.), The Crisis in Modernism: Bergson and the Vitalist Controversy, Cambridge University Press, Cambridge, 1992, pp. 158-163.
} 
"What likelihood is there that, by two entirely different series of accidents being added together, two entirely different evolutions will arrive at similar results? The more two lines of evolution diverge, the less probability is there that accidental outer influences or accidental inner variations bring about the construction of the same apparatus upon them, especially if there was no trace of this apparatus at the moment of divergence." 22

In other words, both the hypothesis of genetic mutations and the hypothesis of selection by adaptation, as well as the combination of the two, fall short of supplying a sufficient explanation for the almost identical structures in such remote lines of evolution.

As to the second point, Bergson argues that neither the concept of small and gradual variation, nor the one of quick and big ones, can explain the development of complex organs, like the eye. ${ }^{23}$ Regarding the first instance, it seems that in the process of development of the organ, each small variation - prior to the organ is completed and functioning well - will be disadvantage to the creature, since it will interrupt rather than help its survival. The small variations, therefore, should be eliminated by natural selection before the organ is completed. Then again, great repeated luck, indeed a miracle, is needed in order to produce abruptly new, complex and well-functioning organs. ${ }^{24}$

Of course, what insures for Bergson the creation and coordination of evolution is the notorious élan vital - the creative force of the universe. This seems unfortunate because, not only does modern biology reject all kind of vitalism, i.e., the belief in some special force needed to produce life, but also it seems like the dispute between vitalism and its antagonist mechanism - has long been decided in favor of the latter. The case, however, is far from being simple. For example, some claim that vitalism is being revived our days under the headings of complex-systems and/or emergentism. ${ }^{25}$ In addition, there are substantial differences between Bergson's vitalism and other forms of vitalism, so much so that one might hesitate to label Begson's approach as vitalistic. ${ }^{26}$ This subject, then, deserves a detailed treatment that cannot be given here. It should, however, be remembered that the concept of élan vital is an expansion and extrapolation of a more fundamental and more defensible concept, that of duration (la durée), or real time. ${ }^{27}$ Thus, and in order to emphasize the relevance of Bergson's alternative reaction to the double scientific revolution while at the same time clarifying this reaction, it is better to direct the discussion to a different, more primal, perspective, one that focuses on a crucial distinction that was drawn by Bergson. This is the epistemological distinction between intellect (l'intelligence) and intuition (l'intuition)

\footnotetext{
${ }^{22}$ H. L. Bergson, The Creative Evolution, p. 54.

${ }^{23}$ Ibid., pp. 64-66.

${ }^{24}$ Ibid.

25 Timothy O'Connor \& Hong Yu,Wong, Emergent Properties (Summer 2015), in E. Zalta (ed.), Stanford Encyclopedia of Philosophy. Retrieved from https://plato.stanford.edu/entries/properties-emergent/ (accessed 29.01.2020). See also: Cécilia Bognon-Küss, Chen Bohang \& Charles T. Wolfe, "Metaphysics, function and the engineering of life: The problem of vitalism," in Kairos. Journal of Philosophy \& Science 20 (2018), pp. 113140; Paul Douglass, "Deleuze's Bergson: Bergson redux," in Frederick Burwick \& Paul Douglass (eds.), The Crisis in Modernism: Bergson and the Vitalist Controversy, Cambridge University Press, Cambridge, 1992, pp. 368-388.

${ }^{26}$ Keith Ansell-Pearson, "Bergson's encounter with biology: Thinking life," in Angelaki 10/2 (2005), pp. 59-72; James DiFrisco, "Elan vital revisited: Bergson and the thermodynamic paradigm," in The Southern Journal of Philosophy 53/1 (2015), pp. 54-73; P. Douglass, "Deleuze’s Bergson: Bergson redux."

${ }^{27}$ See, e.g., Gilles Deleuze, Bergsonism, Zone Books, New York, 1988 (Translated by H. Tomlinson \& B. Habberjam). I will return to this point towards the end of the paper.
} 
and its metaphysical counterpart - the distinction between duration and matter. ${ }^{28}$ These are the most central concepts of the all Bergsonian philosophy and exploring them is probably the best way to understand and appreciate Bergson's criticism of modern science and his positive answer to it. From this angle, it would also be easier to understand Bergson's position about life as such.

\subsection{The Epistemological-Metaphysical Argument: Intellect, Intuition, Time and Space-Matter}

Bergson's basic epistemological claim is that there are two human fundamental forms of knowledge. One is the intellect, which operates through the medium of space, its working tools are concepts and language, and its working method is breaking reality into parts and reconstructing it in varied ways, according to the various human needs.

"... Homogeneous space concerns our action and only our action, being like infinitely fine network which we stretch beneath material continuity in order to render ourselves masters of it, to decompose it according to the plan of our activities and our needs." 29

Intellect, claims Bergson, is the prime human cognitive faculty. Its first aim is pragmatic, but since it works, and works well, to keep humans alive in the material world, it manages to adapt better and better to this world, until it actually fits it and is able to disclose it. ${ }^{30}$ In Bergsonian jargon, matter is extensive, which means that it tends toward spatiality, although is not completely spatial since, as can be understood from the above quotation, space is an ideal projection of the human mind and does not exist outside it. ${ }^{31}$ Matter exists simultaneously, statically and without inner change, ${ }^{32}$ and these traits are exactly what the intellect is looking to find in reality, since they give humans the firm base necessary for their survival. The intellect, then, cuts from the material reality the areas which interest it, freezes them and creates separate and permanent objects, permanent states, permanent relations, which, seemingly, never change and thus offer humans the safe and secure route to the satisfaction of their needs. ${ }^{33}$ For example, on my table I grasp now a pen, a sheet of paper and a book. Each of them seems to me to be an object separated from the others, with certain spatial qualities and certain spatial relations to the other objects in the room. Thanks to their apparently separateness, I can identify them. With the help of concepts and language, I can classify them as (general) things - 'pen', 'book' etc., and thus I can know what to do with

\footnotetext{
${ }^{28}$ Bergson does not always use the word intelligence. Sometimes, especially in The Creative Evolution, he uses the word entendement, which has narrower meaning that refers mainly to the discursive aspect of the intellect. As shall be seen, this is indeed an essential aspect of the intellect, as well as its ability to understand and discriminate, which is captured more precisely by the term intelligence.

${ }^{29}$ Henri L. Bergson, Matter and Memory, Allen \& Unwin, London, 1896/1950 (Translated by N. M. Paul \& W. S. Palmer), p.308.

${ }^{30}$ Henri L. Bergson, The Creative Evolution, ch. 3; The Creative Mind; An Introduction to Metaphysics, Carol Publishing Group, New York, 1934/1903/1992 (Translated by M. L. Andison), pp. 37-45.

${ }^{31}$ For Bergson spatiality means the absolute (mutual) externality of objects and so mutual independence. Matter, on the other hand, is a continuum which its particles interpenetrate each other, and that is why the intellect said to "cut it", or "decompose" it (see H. L. Bergson, The creative Evolution, p. 189, and also below). It might also be noted that on space the Bergsonian position can be read as Kantian. But of course, as soon will become clear, the case is different regarding time, which for Bergson is a primal ontological being. On Bergson's treatment of the Kantian position regarding space and time see, for example: H. L. Bergson, The Creative Evolution, pp. 356362.

32 Although it should be noticed that according to Bergson even in matter there are some areas of indeterminacy, and thus possibility of indeterministic change (and this is why and how freedom and creation are possible for bodily humans. See, for example, H. L. Bergson, Matter and Memory, pp. 326-332).

${ }^{33}$ H. L. Bergson, The Creative Evolution, pp. 151-164.
} 
them - I can use them. Thanks to their spatial characteristics I can later put them back to their place in the room, which seemingly never changes, due the apparently same relations it keeps with other spots in the room.

Therefore, the material sphere and the intellect can be understood as epistemicalmetaphysical counterparts: The inert and homogenous matter lending itself to intellectual treatment of "decomposing according to any law and of recomposing into any system" exactly because it is devoid from inner movement, inner life, inner development. ${ }^{34}$

Beside the intellect, according to Bergson, there is another different human cognitive faculty, one he terms intuition. Intuition, unlike the intellect, is an uninterested, truth-oriented - as oppose to pragmatic - way of knowledge, that forms a direct and inner - not mediated (i.e., through the medium of space) - link to reality. In order to distinguish the two ways of knowledge, Bergson gives an example.

"When you lift your arm you accomplish a movement the simple perception of which you have inwardly; but outwardly, for me, the person who sees it, your arms passes through one point, then through another, and between these two points there will be still other points, so that if I begin to count them, the operation will continue indefinitely. Seen from within, an absolute is then a simple thing; but considered from without, that is to say, relative to something else, it becomes, with relation to those signs which express it, the piece of gold for which one can never make up change." ${ }^{\text {"3 }}$

The intellect first throws the spatial network on the perceptual data, breaking it into different and separate units - the points through which the hand supposedly travels; then reconstructs the data with its tools, i.e., concepts and signs, so the movement can be described, for example, as a series of points on a system of axes. However, this description, argues Bergson, does not capture the essence of movement itself, but it is rather a static and spatial, or intellectual, translation of it. Therefore, the intellect's knowledge of the movement is relative - both to the knower and to the system of signs. The intuition, on the other hand, grasps the movement in one, indivisible act, knows it, claims Bergson, in an absolute manner. ${ }^{36}$

Since intuition is a direct knowledge, it discloses first and foremost the inner life, inner reality, that is to say, the life of consciousness, of which every consciousness being has a direct link to. Since intuition is an absolute knowledge, it reveals, or at least might reveal, to each consciousness being, their true nature. What intuition discovers, according to Bergson, is that consciousness is an unbroken, evolving, qualitative-heterogeneous process $;{ }^{37}$ it discovers, in other words, that the structure of consciousness is that of real time, of duration.

In The Creative Evolution Bergson suggests that intuition developed as a combination of intellect and instinct. I shall not elaborate on this theory here, as doing so will divert the discussion to overly remote territories. ${ }^{38}$ What need to be noticed about it, and more important, about Bergson's epistemological theory, are the following points:

(1) He tries to ground his theory on the assumption of evolution.

\footnotetext{
${ }^{34}$ Ibid., P. 157.

${ }^{35}$ H. L. Bergson, The Creative Mind; An Introduction to Metaphysics, p. 161.

${ }^{36}$ Ibid., pp. 159-162.

${ }^{37}$ See, e.g., Ibid., p. 32.

${ }^{38}$ On this issue see, for example, John Mullarkey, Bergson and Philosophy: An Introduction, Edinburgh University Press, Edinburgh, 1999.
} 
(2) This theory explains science's success and development, mostly the physical sciences' success, by relating the characteristics of the intellect and the material world, so it becomes clear why and how this success occurred. That is to say, the characteristics of the scientific revolution mentioned above - mathematization, geometrization and mechanization of knowledge - are being explained as the natural outcome of the intellect's way of working, which in itself is a natural outcome of adaptation to the material world.

(3) But while Bergson attributes to science and intellect the ability to disclose material realty, he also claims that they cannot reveal all of reality. They cannot reveal reality of life in general, especially of consciousness, simply because these escape the tools and operating system of the intellect and can only be grasped by intuition.

Why does Bergson claim that the intellect cannot grasp the true nature of consciousness and life? Recall that Bergson equates consciousness with real time or duration and characterizes real time - and therefore the stream of consciousness - as an unbroken, evolving, qualitative-heterogeneous continuity. To take an example that Bergson himself gives in order to demonstrate the processes that constitutes consciousness, the formation of the feeling of pity: The first stage of this feeling consists, according to Bergson "... in putting oneself mentally in the place of others, in suffering their pain. ${ }^{\prime 39}$ This element of pity is not, however, the whole feeling because suffering invokes revulsion in humans and deters them, and hence this element alone would cause them to back away from the subject who suffers. But this primal feeling is joined by "the need of helping our fellow men and of alleviating their suffering." ${ }^{40}$ Bergson acknowledges the possibility that this additional element of the feeling is based upon utilitarian consideration that "I myself might suffer in the future," However, he continues, here another emotional factor appears which is a kind of desire to suffer. This element turns the feeling of pity into something noble in our eyes, because it goes above and beyond utilitarian considerations, and with this the feeling of pity reaches its completeness. 42

In this example are manifested all the characteristics of duration mentioned above. Firstly, there is the heterogeneous, or qualitative, multiplicity of the different feelings revulsion, fear, sympathy, nobility - which cannot be reduced to each other. Secondly, this multiplicity is being created over time, that is to say, as a succession of one stage after another. However, thirdly, this is not a succession of atomic units which are external to each other but rather mutual co-permeation and merging. This means that the past is preserved, permeates the present, influences it and, together with it, creates a new reality. This reality is qualitatively, and not quantitatively, different from the preceding reality, because the new feeling created is not the aggregated sum total of the feelings preceded it, but it is distinguished and different from them, and yet includes them.

Bergson maintains that sensations and perceptions, and not only emotions, are fashioned according to the same model of qualitative development. For example, a certain sensation of heat is not just greater or stronger than other sensations of heat that preceded it but is qualitatively different from them as any "close attention" will reveal. ${ }^{43}$ As Lacey points out, every sensation, emotion or other psychological state, involves time and time involves

\footnotetext{
${ }^{39}$ Henri L. Bergson, Time and Free Will, Dover, London, 1889/1957 (Translated by F.L. Pogson), p. 18.

${ }^{40}$ Ibid., p. 19.

${ }^{41}$ Ibid.

42 Ibid.

${ }^{43}$ Ibid., p. 46.
} 
memory. ${ }^{44}$ The events of the past - in the last example these will be the sensations of heat that preceded the present sensation of heat - are preserved and accumulated into a new sensation that is qualitatively different from those that preceded it. In other words, the actuality of the time factor necessitates qualitative change from moment to moment since the past joins up with the present and so creates a new reality.

In Time and Free Will, ${ }^{45}$ Bergson analyses many more examples of perceptions, sensations and emotions, and show them all to be of the same nature of the examples given. Bergson establishes, thus, a firm base to the claim according to which the structure of consciousness is duration. It is also important to notice that, since according to Bergson each event in consciousness includes something completely new - that cannot be reduced to the former events or states - it follows that the structure of consciousness, and hence of real time, is indeterministic, that is, each event in consciousness, while necessarily connected to the past, is also unpredictable and unnecessarily outcome of it. ${ }^{46}$

Now, recall that Bergson's contention is that the intellect's initial goal is pragmatic, namely, to make our actions in the world as efficient as possible in order to satisfy our needs; and that it pursues its goal by dividing the material sphere and stamping the parts as permanent forms, that can be used over and over again. Recall also that the intellect's tools are symbols and signs, that their nature corresponds to their function, meaning they are, in themselves, atomic units that stand for constant and atomic things, relations and properties, and have only external relations; units that represent only the abstract and general aspects of realty, its common and homogeneous, rather than exceptional and heterogeneous, face. If all this is true, then it is clear why, according to Bergson, the intellect cannot grasp the unbroken, heterogeneous, indeterministic process which is consciousness, since the intellect can only know and describe the discrete, un-continuous, homogenous, simultaneous, in short spatial, aspects of the real. ${ }^{47}$

On the same ground, it is possible to apprehend now the distinction drawn by Bergson between real and false time. The later, the normative time of clocks and convention, is a combination of homogeneous, completely discrete, units (seconds, minutes, hours) which - because of its nature, can be thought of as reversible and part of deterministic world. ${ }^{48}$ This is the time that the intellect, which dominates both common sense and science, ${ }^{49}$ constructs and presents as real time. However, according to Bergson it is not so, since real time is a duration: an unbroken, indeterministic, evolving, heterogeneous continuity; duration, that because of its structure, cannot, in principle, be grasped by intellect only by intuition which is a direct, sympathizing introspection that reveal the true nature of the self, nature whose essence is being in time not in space. ${ }^{50}$

\footnotetext{
${ }^{44}$ Alan R. Lacey, Bergson, Routledge, London, 1989, pp. 49-50.

${ }^{45}$ Entitled in French Essai Sur les Données Immédiates de la Conscience.

${ }^{46}$ For example, H. L. Bergson, The Creative Evolution, pp. 1-7; The Creative Mind; An Introduction to Metaphysics, pp. 11-29. See also; Milič Čapek, Bergson and Modern Physics, Reidel, Dordrecht, 1971, pp. 99105.

${ }^{47}$ H. L. Bergson, The Creative Evolution, p. 162.

${ }^{48}$ James W. Felt, Making Sense of Your Freedom, Cornell University Press, Ithaca, NY, 1994; Raz Shpeizer, Henri Bergson and the Problem of Free Will, Resling, Tel Aviv [in Hebrew], pp. 50-68.

${ }^{49}$ H. L. Bergson, The Creative Mind; An Introduction to Metaphysics, pp, 37-45.

${ }^{50}$ The sense of the term sympathy for Bergson is close to its original Greek meaning of sharing feelings or experiences (in Greek sympatheia, which is composed from syn - "together" and pathos -" feeling"). He uses the term first and foremost to indicate the epistemic relation between the conscious knower and their (real) self. See, Ibid., pp. 162-163).
} 
Turning back to Bergson's treatment of life as such, it should become clearer now why Bergson equates life with consciousness, claiming that both share the same structure. ${ }^{51}$ Accepting evolution as a matter of fact, Bergson recognizes in it an evolving stream of heterogeneous forms, which can be created unpredictably in any new direction - similar to the stream of consciousness. It should also become clearer why Bergson claims that science cannot reveal the essence of life, science being the methodization of the intellect way to treat and investigate reality. Recall the characteristics of the scientific revolution that were enumerated in the first section. Mathematics and geometry, which during this revolution became the main tools and means of science, are in themselves the culmination and pure manifestation of the intellect's function and tools. As Bergson stresses and demonstrates in many places, ${ }^{52}$ geometry is the science of space, i.e., of things and qualities that exists simultaneously, meaning, timelessly, without change; while mathematics is the language which takes into perfection all the intellectual properties mentioned above. Thus, argues Bergson, ${ }^{53}$ we find in mathematics

(1) Total separation between the mathematical symbols (the numbers), and therefore between the objects they represent in the world. It is imperative that the numbers will be completely separate and external to each other, for without such separation no act of calculation will be possible. If the arithmetic units will merge with each other, they would lose their meaning and mathematics would collapse.

(2) Permanence - the signs of the mathematical language never change and always have the same meaning (same value).

(3) Homogeneity - the numerical units are perceived during the arithmetical calculi as identical and any quality that might differentiate them is being removed.

(4) Simultaneity - to perform a calculation, or even just to build a number, the numerical units must be placed side by side, so they can be combined in order to create a new number.

This mutual externality of the units, their permanence, the need to place them simultaneously side by side require, according to Bergson, ideal space, i.e., an empty homogeneous environment, in which the arithmetical functions can be treated. ${ }^{54}$ Hence, both mathematics and geometry are meant, by their very nature, only to construct and describe spatial pictures, which are permanent pictures built up from completely homogeneous, external, simultaneous units, and cannot be used to grasp nor describe realty which is a continuous, evolving, heterogeneous process, the reality of real time, of duration. ${ }^{55}$

Duration, then, can be known only through intuition. It is, claims Bergson, an undeniable fact known through a subjective experience of introspection which proves subjectivity itself, ${ }^{56}$ namely, consciousness - the one which science denies in the name of objectivity - to be primal fact. We come to know consciousness and its structure through consciousness. Intuition is consciousness tuned-in to itself and becomes one with itself. What is more, since the study of duration reveals, according to Bergson, its indeterministic and

\footnotetext{
${ }^{51}$ Henri L. Bergson, Mind energy, Henry Holt \& Company, New York, 1929 (Translated by H. W. Carr), pp. 22-23; The creative evolution, p. 207.

${ }^{52}$ See e.g., H. L. Bergson, The Creative Evolution, ch. 3; Time and Free Will, ch. 2.

${ }^{53}$ See especially, H. L. Bergson, Time and Free Will, pp. 75-85.

${ }^{54}$ Ibid., pp. 77-78.

${ }_{55}^{5}$ M. Čapek, Bergson and Modern Physics, pp. 139-140.

${ }^{56}$ H. L. Bergson, The Creative Evolution, pp. 1-2; The Creative Mind; An Introduction to Metaphysics, pp, 159163;
} 
immaterial (in Bergsonian terminology non-spatial) nature, the door is re-opened to the old beliefs in freedom and spirituality. Freedom being the creative way in which the durational consciousness can act, produces an unnecessary and unpredictable future ${ }^{57}$ spirit being its timely - rather than spatial - structure.

\subsection{Consciousness and Life}

We can see, then, that for Bergson there is an essential difference between science and life-science. For him, the essence of Being lies in life and the essence of life lies in consciousness. Hence for Bergson, it is the supposedly natural importing of the scientific method that works so well in the inanimate sphere to the animate sphere that causes confusion and mistake in the scientific and philosophical understanding and plays a major role in creating the crisis of the modern era. Notice that Bergson is not claiming that science should not at all investigate life, only that this investigation has clear limits, which are the limits of the scientific method and the intellect in general.

It might be argued, as indeed it has been, that the extrapolation made by Bergson from the sphere of consciousness to the sphere of life in general is not satisfactorily justified and therefore, in the light of modern-biology's rejection of the concept of élan vital, one should reject Bergson's concept of life altogether. ${ }^{58}$ However, it should be noted, first, that even if it is true that the plausibility of the Bergsonian position regarding life-in-general is not as strong as the plausibility of his position regarding consciousness, since only the latter can be known directly, the question should not be whether something like the élan vital is true, but rather whether life-in-general displays the qualities that Bergson claims that consciousness is endowed with. In other words, is real time, duration, a constitutive element of life? And here, the answer that Bergson gives is at least as plausible as any other answer that has been given until today. Second, and more importantly, even if one only accepts the claim according to which consciousness constitutes at least part of the human essence; and if one also accepts the Bergsonian intuition of the durational structure of this consciousness, which, I have tried to show, stands on a strong and firm ground, then one should accept the strength of the Bregsonian alternative: If a fundamental element of our existence is indeed duration, then the gate - even if it is leading to a different path than the one followed by the Bersonian evolutional theory - is reopened to the possibilities of subjectivity, freedom and autonomy; the same possibilities that seemingly were shut down by the double scientific revolution which turned the human world upside down.

\section{CONCLUSION}

To return to the three consequences of the scientific revolution which were described earlier, it is possible to see, first, that as against both modernism and postmodernism, Bergson secures for philosophy an important place in the sphere of truth-seeking, since for him philosophy is, or at least should be, the bearer of the method of intuition, and therefore the prime discipline that should investigate life and spirit. Second, that against the philosophical and cultural dichotomy of scientism on the one hand and anti-scientism and

\footnotetext{
${ }^{57}$ For Bergson, although freedom is always possible - because of the durational structure of consciousness only rarely do people exert their ability to act freely, since they bound to their habits and, in a dipper level, to their superficial-intellectual self which, according to Bergson, conceal from them their true free nature, exactly because its mechanistic and deterministic biases. On this, see H. L. Bergson, Time and Free Will, pp. 163-173. ${ }^{58}$ For a sympathizing discussion on the apparently jump made by Bergson from the immediate data of consciousness to the outer reality see Francis C. T. Moore, Bergson: Thinking Backwards, Cambridge university Press, Cambridge, 1996, ch. 8.
} 
fundamentalism on the other, Bergson offers a way that at once respects science, acknowledges its strength and contribution, but nevertheless limits it scope, and thus does not turn it into a new religion. As has been shown, for Bergson science should investigate the realm of matter because its method of investigation, that is, the intellectual method, matches matter and correlates to it, as an outcome of extended period of adaptation to the material environment. However, for the same reason, science cannot adequately and accurately investigate life and spirit, since the structure of life and spirit is essentially different from the structure of matter, and so is beyond the grasp of the intellect per se. Third, that by drawing the limits of science and intellect on the one hand, while on the other hand developing the method of intuition in order to dive into the depths of subjective experience, Bergson seeks to re-establish the truth, or at least the possibility of truth, of human subjectivity, freedom, creativity and autonomy, in short, sense of telos in life, that seems to have been taken away from humanity during the process of the scientific revolution.

Reflecting our days, when an ever-growing dichotomy is developing between religious fundamentalism on one side and scientism on the other; when a seemingly unbridged gulf exists between the layman and the scientist, as much as between the postmodern and the modern philosopher; one can find in Bergson an inspiration for a third and middle way. This is a way which accepts science but does not worship it; which accepts the religious aspirations but does not confuse them with blind faith; which accepts the need for critical thinking but does not confuse it with skepticism. This is a way which embraces evolution as an ever-growing development and progression yet does not discard the old beliefs - neither in truth nor in humanity.

One should not, however, understand Bergson's philosophy to be solely, or even mainly, a moral one, that is, a philosophy which aims only to rescue our fundamental beliefs. To the contrary, what I have tried to suggest here is that we should understand it first and foremost as a truth-seeking philosophy, that claims that far as science and intellect can and do go they will never, in principle, be able to completely comprehend life in their pure sense as duration or consciousness - and so as subjectivity, freedom and creativity. In order to understand these, we need, according to Bergson, a different method of knowledge, a different approach to reality, one that should coexist and cooperate with science and does not aim at replacing it. This method Bergson termed intuition, and its object he claimed to be real time, or real life.

\section{BIBLIOGRAPHY:}

[1] Ansell-Pearson, Keith, "Bergson's Encounter with Biology: Thinking Life," in Angelaki, 10/2 (2005), pp. 59-72.

[2] Bergson, L. Henri, The Creative Evolution, Dover, New York, 1907/1983 (Translated by A. Mitchell).

[3] Bergson, L. Henri, Matter and Memory, Allen \& Unwin, London, 1896/1950 (Translated by N. M. Paul \& W. S. Palmer).

[4] Bergson, L. Henri, Mind energy, Henry Holt \& Company, New York, 1929 (Translated by H. W. Carr).

[5] Bergson, L. Henri, The Creative Mind; An Introduction to Metaphysics, Carol Publishing Group, New York, 1934/1903/1992 (Translated by M. L. Andison).

[6] Bergson, L. Henri, Time and Free Will, Dover, London, 1889/1957 (Translated by F.L. Pogson).

[7] Bognon-Küss, Cécilia, Bohang, Chen \& Wolfe, T. Charles, "Metaphysics, Function and the Engineering of Life: The Problem of Vitalism," in Kairos. Journal of Philosophy \& Science, 20 (2018), pp. 113-140.

[8] Boyer, C. Carl, A History of Mathematics, Wiley, New York, 1968.

[9] Bursill-Hall, Piers (2002, May 1). Why do We Study Geometry? Answers Through the Ages. The Department of Pure Mathematics and Mathematical Statistics, University of Cambridge, (C2001, https://www.dpmms.cam.ac.uk/ piers/F-I-G_opening_ppr.pdf, 20.01.2020. 
[10] Burtt, A. Edwin, The Metaphysical Foundations of Modern Science, Routledge \& Kegan Paul, London, 2001.

[11] Čapek, Milič, Bergson and Modern Physics, Reidel, Dordrecht, 1971.

[12] Carvalho, C. Magda \&. Neves, P. Maria, "Building the 'True Evolutionism': Darwin's Impact on Henri Bergson's Thought," in Revista Portuguesa de Filosofia, 66/3 (2010), pp. 635-642.

[13] Cohen, H. Floris, The Scientific Revolution: A Historiographical Inquiry, University of Chicago Press, Chicago, 1994.

[14] Darwin, R. Charles, On the Origin of Species by Means of Natural Selection, or the Preservation of Favoured Races in the Struggle for Life, Penguin, London, 1859/1985.

[15] Deleuze, Gilles, Bergsonism, Zone Books, New York, 1988 (Translated by H. Tomlinson \& B. Habberjam).

[16] DiFrisco, James, "Elan Vital Revisited: Bergson and the Thermodynamic Paradigm," in The Southern Journal of Philosophy, 53/1 (2015), pp. 54-73.

[17] Double, Richard, Metaphilosophy and Free Will, Oxford University Press, New York, 1992.

[18] Douglass, Paul, "Deleuze's Bergson: Bergson Redux," in Frederick Burwick \& Paul Douglass (eds.), The Crisis in Modernism: Bergson and the Vitalist Controversy, Cambridge University Press, Cambridge, 1992, pp. 368-388.

[19] Eco, Umberto, Foucault's Pendulum, Ballantine Books, New York, 1989 (Translated by W. Weaver).

[20] Felt, W. James, Making Sense of Your Freedom, Cornell University Press, Ithaca, NY, 1994.

[21] Freud, Sigmund, A General Introduction to Psycho-Analysis, Boni \& Liveright, New York, 1922 (Translated by G. Stanley).

[22] Hicks, R. C. Stephen, Explaining Postmodernism: Skepticism and Socialism from Rousseau to Foucault, Scholargy Publishing, Tempe, AZ, 2004.

[23] Lacey, R. Alan, Bergson, Routledge, London, 1989.

[24] Lyotard, Jean-François, The Postmodern Condition: A Report on Knowledge, Minnesota University Press, Minneapolis, 1984 (Translated by G. Bennington \& B. Massumi).

[25] Machamer, K. Peter (ed.), The Cambridge Companion to Galileo, Cambridge University Press, Cambridge, 1998.

[26] McKay, P. John, A History of Western Society: From the Renaissance to 1815 , Vol. B ( $8^{\text {th }}$ ed.), Bedford/St. Martin's, Boston, 2005.

[27] Moore, C. T. Francis, Bergson: Thinking Backwards, Cambridge university Press, Cambridge, 1996.

[28] Mullarkey, John, Bergson and Philosophy: An Introduction, Edinburgh University Press, Edinburgh, 1999.

[29] Nickles, Thomas, Scientific Revolutions (winter 2017), in E. Zalta (ed.), Stanford Encyclopedia of Philosophy, https://plato.stanford.edu/archives/win2017/entries/scientific-revolutions, 29.01.2020.

[30] O'Connor, Timothy \& Wong, Hong Yu, Emergent Properties (Summer 2015), in E. Zalta (ed.), Stanford Encyclopedia of Philosophy, https://plato.stanford.edu/entries/properties-emergent/, 29.01.2020.

[31] Orel, Vitezslav, Mendel, Oxford University Press, Oxford, 1984 (Translated by S. Finn).

[32] Rorty, Richard, Objectivity, Relativism, and Truth: Philosophical Papers, Vol. 1, Cambridge University Press, Cambridge, 1991

[33] Rorty, Richard "Philosophy as a Kind of Writing: An Essay on Derrida," in New Literary History, 10/1 (1978), pp. 141-160.

[34] Shapin, Steven, The Scientific Revolution, The University of Chicago Press, Chicago, 1996.

[35] Shpeizer, Raz, Henri Bergson and the Problem of Free Will, Resling, Tel Aviv [in Hebrew].

[36] Wallace, B. Alan, The Taboo of Subjectivity: Toward a New Science of Consciousness, Oxford University Press, Oxford, 2004.

[37] Westfall, S. Richard, The Construction of Modern Science: Mechanisms and Mechanics, Cambridge University Press, Cambridge, 2009.

[38] Wolsky, D. I. Maria \& Wolsky, A. Alexander, "Bergson's Vitalism in the Light of Modern Biology," in Frederick Burwick \& Paul Douglass (eds.), The Crisis in Modernism: Bergson and the Vitalist Controversy, Cambridge University Press, Cambridge, 1992, pp. 158-163.

[39] Wootton, David, The Invention of Science: A New History of the Scientific Revolution, Penguin, London, 2015 